Indonesian Journal of Applied Linguistics, Vol. 3 No. I, July 2013, pp. 8I-I02

\title{
THE EFFECTS OF REFLECTIVE TEACHING ON AN INTENSIVE TEACHER TRAINING PROGRAM
}

\author{
Mei Hua Lan \\ Wenzao Ursuline College of Languages, Taiwan \\ email:99030@mail.wtuc.edu.tw \\ Kai-Ping Wang \\ Shu-Zen Junior College of Medicine and Management, Taiwan \\ email: kentwang@ms.szmc.edu.tw
}

\begin{abstract}
The preliminary case study was conducted to understand the effects of reflective teaching approach on English teachers' teaching performances in a short-term intensive teacher training program, and to know the participating English teachers' feedback to the program. Totally 13 English teachers, who had taught English for 1 to 5 years, participated in this program for 3 weeks with 54 instruction hours. During the intensive program, teachers were asked to design lesson plans and demonstrate their lessons, while their peers, other experienced teachers, provided them with constructive feedback. In addition, the presenters self-assessed and reflected on their own teaching. Through several cycles of teaching demonstrations, peer-assessments, self-assessments and reflections, most teachers indicated that the reflective teaching approach was beneficial for sharpening their teaching skills, equipping them with additional teaching strategies and class management skills, and raising their awareness of the needs for examinations of their teaching reflectively in the future, and the importance of reflection of their own teaching for improvements. To give the teachers more inputs and inspirations, experienced teachers with creative teaching ideas were invited as guest speakers, and positive feedback to the guest speeches was also drawn. The findings of this study were expected to provide some pedagogical inspirations for the related fields, especially English teacher training in EFL contexts.
\end{abstract}

Keywords: Reflective Teaching; Professional Development; Teaching English to Young Learners

\section{PENGARUH PEMBELAJARAN REFLEKTIF ATAS PROGRAM PELATIHAN GURU INTENSIF}

Abstrak: Kajian pendahuluan ini merupakan sebuah studi kasus yang dilakukan untuk 
memahami pengaruh pendekatan pengajaran reflektif terhadap kinerja mengajar guru bahasa Inggris dalam program intensif pelatihan guru, dan untuk mengetahui umpan balik terhadap program yang mereka ikuti. Tiga belas guru bahasa Inggris yang memiliki pengalaman mengajar 1 sampai 5 tahun ikut berpartisipasi dalam program pelatihan 3 minggu dengan 54 jam pelatihan. Selama program intensif tersebut, guru diminta untuk membuat rencana pembelajaran dan melaksanakan rencana pembelajaran tersebut, sementara guru-guru yang lainnya memberikan umpan balik yang konstruktif. Selain itu, guru yang melaksanakan rencana pembelajaran tersebut melakukan penilaian diri dan melakukan refleksi mengenai pengajarannya. Melalui beberapa siklus peragaan mengajar, penilaian teman sebaya, penilaian dan refleksi diri, kebanyakan guru berpendapat bahwa pendekatan pengajaran reflektif berguna untuk mempertajam keterampilan mengajar, memperkaya strategi mengajar dan keterampilan pengelolaan kelas, dan meningkatkan kesadaran mereka terhadap pentingnya memperhatikan pengajaran secara reflektif mereka di masa depan dan pentingnya refleksi terhadap pengajaran mereka. Untuk memberikan input dan inspirasi kepada mereka, guru-guru berpengalaman yang memiliki ide-ide kreatif diundang sebagai pembicara tamu, dan umpan balik positif dari mereka dirangkum. Hasil temuan dari kajian ini diharapkan mampu memberikan inspirasi pedagogis bagi bidang yang berkaitan, terutama pelatihan guru bahasa Inggris dalam konteks EFL

Katakunci: pembelajaran reflektif; pengembangan profesi; pengajaran bahasa Inggris untuk anak usia dini

With recent changes of English language policies, the Ministry of Education of Taiwan has encouraged extensive trainings and certifications of elementary English teachers to enhance better language teaching quality of early language education in Taiwan. For certifications and professional development, the local government in Kaohsiung, in southern Taiwan, sponsored English teachers to take credit courses during their summer vacation, and hoped to assist teachers to learn more practical English teaching techniques or new pedagogies for teaching English four skills. For this reason, the researcher of the study gained the opportunity to conduct a research on the effects of reflective teaching on the teaching performances of English teachers in elementary schools, and the study hoped to help teachers in practice to reflect on their own teaching, and figure out ways to improve their own English teaching to young learners.

Recently, reflective teaching, which refers to critical examinations of our motivation, thinking, and practice (Bailey, Curtis \& Nunan, 2001), has been highlighted and re-emphasized in the educational field, especially for teacher training. The fundamental 
purposes of reflective teaching are to evoke teachers' self-awareness and creativity in teaching, and to enhance teachers' active participations in constant searches for reasonable and effective solutions to their own teaching problems in teaching practices in order to improve their teaching eventually. In many reflective teaching studies, the action research method has often been employed to assist teachers to re-examine their teaching goals and objectives during the teaching processes, and to solve relevant teaching problems across the processes. Based on the action research framework, the recent study intends to understand the effects of reflective teaching and English teachers' feedback to the approach in the short-term teacher training program. The research findings are expected to provide pedagogical contributions in the relevant fields.

Generally speaking, reflective practices can be considered as being able to examine our own professional behaviors and practice for improving our professional performances and developing relevant skills (Clarke \& Croft, 1998). Hence, the professional development and improvement may involve different perspectives in our professions, such as our knowledge, skills, attitudes and awareness that we change or adapt through reflective teaching (Narvaéz, 2010). According to Bailey et al. (2001) reflective teaching involves critical examination of our motivation, thinking, and practice. That is, we cannot say that we are reflective teachers if we only plan our lessons carefully and mark learners' papers.

As Kemmis (1985) put it, reflection is a process which involves an inward examination of our thoughts and thought processes, and an outward consideration of the situation in which we find ourselves. In other words, reflection is a mirror to practice, yet we need to develop some positive attitudes for being reflective teachers, being open-minded, responsible, and dedicative. According to Narvaéz (2010), we will certainly change our beliefs, attitudes, skills, knowledge and awareness with these attitudes and with reflective teaching.

However, reflective teaching is a cyclical process and it is a skill that can be developed over time (Narvaéz, 2010). When reflective teachers started teaching, they might ask themselves some questions, reflecting on how their class had been and how they could improve it for next time. However, as the time passes by, those teachers might incorporate more elements into their reflections since they are aware and have more knowledge. Once reflective teachers start to implement the changes inspired by reflective teaching, then the reflective and evaluative cycle begins again. In a word, reflective teaching is a process with cycles of reflections, modifications and evaluation during the teaching processes across time.

Reflective teaching drew its 
theoretical framework from the works of Dewey (1933) and Schön (1983). As Dewey (1933) argued, reflection is an active and constant process to have in-depth thinking and examinations of personal beliefs, theoretical basis of practice and the cause-effect relationships of events in order to solve problems. According to Schön (1983), "reflection-in-action" occurs in the experience when professionals connect their feelings to theories to inform their actions in the situation as it happens. On the other hand, "reflection-on-action" takes place as spending time exploring how and why reactions to an encounter unfolded. Both facets of reflection enables professionals learn to frame and reframe complex and ambiguous problems, test out various scenarios and modify their actions as a result (Schön, 1987). Kemmis (1985) further pointed out that reflection is a process of internal and external debates to help one to better understand his or her thinking process. In a word, the theory proposed by Schön based on Dewey's philosophy is important in explaining how processes, experiences and understanding generated through reflection can improve on what we do when we take reflection in and on action together (Rodman, 2010).

Reflective teaching has been employed for pre-service teacher training and professional development of in-service teachers. According to Moon (2006), reflective engagement helps pre-service teachers to actively consider and reconsider beliefs and practices that allow them to move toward metacognition in teaching. Through the processes of consideration and reconsideration of their beliefs and teaching, pre-service teachers can improve their abilities to monitor their decisions about what and how they teach. It is a major responsibility of teacher education to facilitate a reflective, self-monitoring practice and to promote such a practice as a critical and active habit that improves the pre-service teachers' pedagogical abilities (Rodman, 2010). Similarly, Costa and Kallick (2000) pointed out that experience in the classroom can reinforce the concept that self-reflection enables pre-service teachers to construct meanings from their work in it. Likewise, Pedro (2005) indicated that reflective teaching encourages pre-service teachers to practice critical thinking about their practice. Specifically, reflective teaching assists pre-service teachers to develop their abilities to examine their own concepts, theories and beliefs about teaching and subject matter (Posner, 2005; Rodman, 2010).

In several empirical studies, effects of reflective teaching of pre-service teachers have been examined and studied. For example, Pedro (2005) conducted a qualitative, interpretive study to examine how five pre-service teachers constructed meanings of reflective practice, and how these meanings informed their practice. Downey (2008) focused on examinations of the ways 
guided reflection of a recorded teaching assignment enhanced subjects' development of the knowledge, skills and dispositions needed to be an effective educator. Danielowich (2007) explored how science teachers could deal with the conflicts between the teaching objectives and real practice through reflections in a variety of contexts. Orland-Barak and Yinon (2007) guided pre-service teachers to reflect on class interactions to enhance the integrations of theory and practice. In Moran (2007), it was found that reflective practice was helpful for pre-service teachers' self-modifications during the teaching. The findings of these studies support the notion that pre-service teachers have the ability to develop a better understanding of the skills and knowledge and self-awareness through reflection. They point out how reflective practice can and should be encouraged in different pedagogical contexts (Rodman, 2010).

In Taiwan, a couple of empirical studies were conducted to understand the effects of reflective teaching in practice. Chio (2004), for instance, investigated senior teachers' teaching reflections, and suggested that reflective teaching was significant for teachers' professional development. Yang (2004) conducted a research on professional development of elementary school math teachers' reflective teaching skills, employing social networking to guide math teachers' reflections. The study found that most teachers mainly reflected on teaching methods while reflections on practices were comparatively fewer; however, teachers' teaching became more open, student-centered after reflective teaching.

In addition, Tsai (2004) investigated the nature of reflective teaching of pre-service teachers and found that the reflection results were restricted by the limited abilities of pre-service teachers so that the pre-service teachers were not able to put the inspirations from reflective teaching into practice instantly. Tzeng (2002) examined pre-service teachers' understanding and concepts of class management and found that pre-service teachers had different levels of reflections depending on various contexts. The study findings of Yuen (2005) indicated that reflective teaching was beneficial for enhancing learners' confidence and being considerate in teaching.

The findings of the previous studies suggest the positive effects of reflective teaching on teacher training and teachers' professional development. However, limited research has been conducted to employ reflective teaching approach for in-practice teachers who teach English as a foreign language to young learners that might need more teachers' scaffolding and clear teaching objectives and procedures. Based on the previous research findings of reflective teaching in teacher training, teachers' professional development and 
the framework of action research, the current research intends to know English teachers' feedback to the reflective teaching approach in the short-term teacher training program and how it might assist them professionally.

\section{METHOD}

Totally, 13 subjects, 2 male and 11 female teachers, were involved in this study. All of the subjects were teaching English to 3rd to 6th graders in elementary schools in southern Taiwan, and they have taught English for less than 5 years. Half of the subjects were full-time teachers while the other half was part-time teachers. Most of the teachers in this study were able to lecture in English fluently.

The instruments employed in this study include a Feedback Questionnaire on the Reflective-Teaching-Based Course, a Questionnaire on Reflective-Teaching, a Self-Assessment Form of Teaching Demonstration and a Peer-Assessment Form of Teaching Demonstration. The Feedback Questionnaire on the Reflective-Teaching-Based Course contains 25 Likert-scale items and 4 open-ended questions to know the subjects' feedback to the overall course design and guest speeches. The Questionnaire on Reflective Teaching had 2 parts with 15 Likert-scale items and 1 open-ended question regarding the gained inspirations and reflections to relevant activities for reflective teaching. The Self-assessment and Peer-assessment Forms of Teaching Demonstration contained identical items to guide the teachers to self-evaluate and assess their peers' teaching demonstration from 5 aspects, including content design appropriateness, presentation clearness, successful teaching strategy applications, class management effectiveness and good communication skills.

Before the implementations of reflective teaching (the preparation phase), all subjects were asked to demonstrate a pre-study teaching and it served as a reference for diagnosing the English teachers' instructions. Then, lectures, pedagogical tasks and the reflective teaching approach was applied to help the English teachers to self- assess, peer-assess and reflect on their own 2 teaching demonstrations for diagnosis and consultations. Also, 2 experienced elementary school teachers for were invited to share some creative ideas for teaching English to young learners. The training program lasted for 3 weeks with 54 instruction hours, and the course offered intensive daily lectures and discussions. Finally, the subjects were asked to complete the feedback questionnaires anonymously without the class instructor's presence, and they were also guided to provide their responses to the course design, reflective teaching and guest speeches. Quantitative and qualitative analyses were then conducted for better under- standing of the participants' feedback and the effects of reflective teaching

\section{FINDINGS AND DISCUSSION}

In this study, descriptive statistics were 
applied for analyzing the quantitative data, as shown in Table 1 to Table 4. Besides, qualitative analyses were for describing subjects' responses to the open-ended questions in questionnaires. With both quantitative and qualitative analyses, we can have a more holistic picture on the effects of reflective teaching.

According to Table 1, the subjects in this study indicated positive feedback to the course design. Specifically, all teachers were satisfied with the course incorporating guest speeches by experienced teachers (item 1), the lectures by the course instructor (item 4) and the relevant and practical class activities in this course (item 5). Also, most of the teachers thought the course contents were appropriate (item 2), the course design and contents met their needs and expectations (item 6), and the amounts of content were appropriate (item 15).

In addition, the English teachers indicated that the reflective-teaching- based course was beneficial in several ways. For example, the course's incorporations of new ideas and technology (item 3), introduction of a variety of teaching approaches (item 7) and the supplementary materials provided by the class instructor (item 8) were practical and helpful for their teaching.

Furthermore, all teachers thought that the course design was helpful for them to integrate professional knowledge, theoretical backgrounds and practice (item 9). The course contents also assisted them to improve their teaching abilities (item 10), and the course design equipped them well and made them confident of their future teaching (item 12). Finally, the participants of the study responded that the course design inspired them in different ways. For instance, the course contents assisted them to improve their teaching abilities (item 11), to reflect on their own teaching, and teachers try to actively improve their weaknesses (item 13), while the sharing among teachers inspires them with more teaching strategies (item 14). In sum, the course design of this study employing reflective teaching drew positive results and feedback and was considered appropriate and helpful for teachers' teaching practice and professional development.

The qualitative analysis results (see Appendix) lent support for the quantitative data discussed in the previous sections. Particularly, most subjects provided positive feedback to the rich resources provided by the class teacher. They also pointed out that the class discussions, comments and suggestions by the peers and class teachers after the teaching demonstrations and the review of relevant language teaching methods and approaches were extremely helpful for them. Some teachers responded that the course design and reflective teaching assisted them to constantly re-examine their objectives and teaching strategies or class activity design, and to inspire them to try innovative or new ways of teaching. The qualitative results are consistent with the quantitative analysis of feedback questionnaire and 
relevant studies as mentioned before. The following are some excerpts from the teachers' feedback to the open-ended questions in the course feedback questionnaire.

The comments and suggestions provided by peers and the class teacher after teaching demonstrations were very practical. In the course, teacher reviewed some language teaching approaches and recalled my memories. (T002)

The course helped me rethink my previous course and activity designs and re-evaluate if they are consistent with my teaching objectives. (T009)

The course helped me understand how to incorporate on-line resources to enhance my students'learning, but I need to pay attention to if the applications of on-line resources would be consistent with my teaching needs and objectives. Also, the learners play a very critical role in my course design. (T011)

The course encouraged me to try new teaching approaches and techniques. For example, the final story-telling demonstration task was quite interesting and challenging, but they are helpful.

T invited some Ts (guest speakers) to share their practical experiences. They really gave me some good ideas, and I couldn't wait to try them in my class. (T013)

In sum, the participating teachers benefit from the reflective-teachingbased course, and the course assisted them to relate the practices to the prior knowledge, re-evaluate their own teaching, observe good teaching techniques and adapt observed helpful teaching strategies to their class.

According to Table 2, most subjects indicated positive feedback to the reflective teaching approach. Specifically, all teachers thought that teaching demonstrations and reflective teaching activities assisted them to come up with good ways to improve their teaching (item 5). Also, teachers agreed that teaching demonstrations and reflective teaching activities helped them try to change and adopt new teaching approaches (item 10). In addition, all teachers indicated that they would discuss with other teachers about ways to improve teaching after the teaching demonstrations and reflective teaching activities (item 12).

The above results were consistent with the findings of the previous studies that suggested advantages of reflective teaching for inspiring teachers to adopt new or better ways to improve their teaching (Rodman, 2010), for teacher's modifications of their current teaching (Moon, 2006), and for constantly being reflective on their own teaching (Moran, 2007).

Furthermore, the results of Table 2 indicated that more than $90 \%$ of the teachers thought that the reflective teaching practice in the training program helped them be aware of their strengths and weaknesses of their own teaching and be more willing to accept others' suggestions. 
Table 1: Teachers' feedback to the course based on reflective-teaching

\begin{tabular}{|c|c|c|c|c|c|c|}
\hline Items & Mean & 5 & 4 & 3 & 2 & $\mathbf{1}$ \\
\hline $\begin{array}{l}\text { 1. I'm satisfied with the course incorporating guest } \\
\text { speeches by experienced teachers. }\end{array}$ & 4.38 & 39 & 61 & 0 & 0 & 0 \\
\hline 2. I think the contents of this course are appropriate. & 4.38 & 39 & 61 & 0 & 0 & 0 \\
\hline $\begin{array}{l}\text { 3. The course's incorporations of new ideas and } \\
\text { technology are beneficial for my teaching. }\end{array}$ & 4.38 & 39 & 61 & 0 & 0 & 0 \\
\hline $\begin{array}{l}\text { 4. I am satisfied with the lectures by the course } \\
\text { instructor, who is well-prepared. }\end{array}$ & 4.62 & 62 & 38 & 0 & 0 & 0 \\
\hline 5. I am satisfied with the relevant and practical class & 4.62 & 62 & 38 & 0 & 0 & 0 \\
\hline
\end{tabular}
activities.

6. The course design and contents meet my needs and $\begin{array}{lllllll}4.31 & 31 & 69 & 0 & 0 & 0\end{array}$ expectations.

7. A variety of teaching approaches shared in the class $\begin{array}{lllllll}4.62 & 62 & 38 & 0 & 0 & 0\end{array}$ are very helpful for my teaching practices.

$\begin{array}{llllllll}\text { 8. The supplementary materials provided by the class } & 4.54 & 54 & 46 & 0 & 0 & 0\end{array}$ instructor are practical and helpful for my teaching.

9. The course design is helpful for me to integrate $\begin{array}{lllllll}4.31 & 39 & 54 & 8 & 0 & 0\end{array}$ professional knowledge, theoretical backgrounds and practice.

10. The course contents inspire my creativities in $\begin{array}{llllllll}4.62 & 62 & 38 & 0 & 0 & 0\end{array}$ teaching.

11. The course contents assist me to improve my $\quad \begin{array}{lllllll}4.54 & 54 & 46 & 0 & 0 & 0\end{array}$ teaching abilities.

12. The course design equips me well and makes me $\begin{array}{llllll}4.38 & 39 & 61 & 0 & 0 & 0\end{array}$ confident of my future teaching.

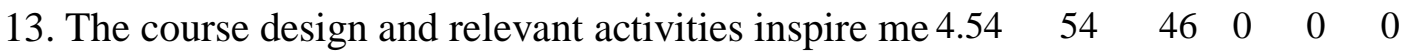
to reflect on my own teaching, and try to actively improve my weaknesses.

14. The sharing among teachers inspires me with more $\begin{array}{llllll}4.54 & 54 & 46 & 0 & 0 & 0\end{array}$ teaching strategies.

15. The amounts of content are appropriate. $\quad \begin{array}{lllllll}4.31 & 39 & 54 & 8 & 0 & 0\end{array}$ 
Table 2: Teachers'feedback to reflective-teaching

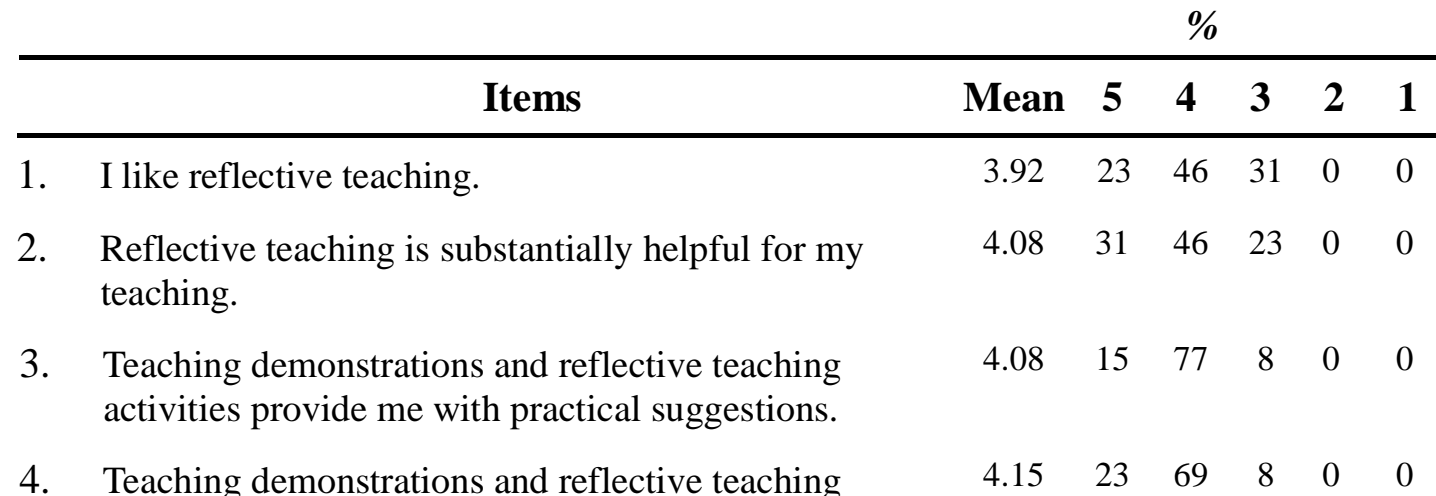
activities helps me understand my teaching strengths and weaknesses.

5. Teaching demonstrations and reflective teaching activities assist me to come up with good ways to improve my teaching.

6. Teaching demonstration and reflective teaching help me understand students' needs better.

7. Teaching demonstrations and reflective teaching activities equip me with more strategies and skills for English-Only instructions.

8. Teaching demonstrations and reflective teaching activities equip me with better class management skills.

9. Teaching demonstrations and reflective teaching activities enhance teacher-student interactions.

10. Teaching demonstrations and reflective teaching activities help me try to change and adopt new teaching approaches.

11. After the teaching demonstrations and reflective teaching activities, I start to reflect on my teaching actively.

12. After the teaching demonstrations and reflective teaching activities, I will discuss with other teachers about ways to improve teaching.

13. After the teaching demonstrations and reflective teaching activities, I will keep on thinking how to improve my teaching

14. After the teaching demonstrations and reflective teaching activities, I am more likely to accept other people's suggestions in order to improve teaching.

15. I think the teaching demonstrations and reflective teaching activities are useless, and they are a waste of time. 
Accordingly, most teachers (92\%) agreed that teaching demonstrations and reflective teaching activities provided them with practical suggestions (item 3), and teaching demonstrations and reflective teaching activities helped them understand their teaching strengths and weaknesses (item 4). Also, most teachers $(92 \%)$ indicated that they started to reflect on their teaching actively after teaching demonstrations and teaching activities (item 11), while they were more likely to accept other people's suggestions to improve teaching after the teaching demonstrations and reflective teaching activities (item 14). The above results confirm the findings of the previous studies that suggested the positive effects of reflective teaching on teacher's critical thinking (Pedro, 2005) and actively involved in the reflection processes to re-examine their beliefs and objectives for better teaching (Posner, 2005; Rodman, 2010).

Finally, most teachers (60\% to $70 \%$ ) liked reflective teaching and agreed that reflective teaching could be helpful for their teaching in several ways. According to the results in Table 2, most teachers (about 70\%) liked reflective teaching (item 1), and $77 \%$ of them thought that reflective teaching was substantially helpful for their teaching (item 2). Also, more than $70 \%$ of the teachers indicated that teaching demonstration and reflective teaching helped them understand students' needs better (item 6), and the relevant reflective activities equipped them with more strategies and skills for English-Only instructions (item 7). Furthermore, most teachers (about 70\% to $80 \%$ ) agreed that teaching demonstrations and reflective teaching activities equipped them with better class management skills (item 8), and they enhanced teacher-student interactions (item 9). Finally, $85 \%$ of the teachers indicated that they would keep on thinking how to improve their teaching after the teaching demonstrations and reflective teaching activities (item 13), and more than $60 \%$ of them didn't think that the teaching demonstrations and reflective teaching activities were useless, but a waste of time.

Like the quantitative results discussed in the previous sections, most subjects indicate that reflective teaching helps them re-examine their own teaching, strengths, weaknesses and objectives, and constantly reflect on their own teaching. Also, they can learn from each other through teaching demonstrations, and improve their own. In addition, some of them points out that reflective teaching helps them modify or adopt some concepts (e.g. new understanding of the role of warm-up activities in each section by T001).

The following are some excerpts from the subjects' feedback to the open-ended questions in the reflective-teaching questionnaire. 
The course helped me re-examine teaching of English reading, and the relationship between English reading and writing. (T001)

Through observations, feedback or comments as well as theoretical backgrounds, we are provided with good ideas and chances for constant improvements in teaching. (T007)

The course helped me rethink my previous course and activity designs, and

re-evaluate if they are consistent with my teaching objectives. (T009)

The above findings supported the conclusions of the previous studies (Chio, 2004; Downey, 2008; Narvaéz, 2010; Tzeng, 2002) that argued for the positive effects of reflective teaching on equipping teachers with better professional skills and knowledge (e.g. instructional strategies or techniques, class management skills and teacher-student interactions, etc.)

In sum, the findings of the present study support the conclusions of previous studies about the positive effects of reflective teaching on teachers' professional development in terms of teaching and class management strategies, and on teachers' self-awareness of practicality of their teaching beliefs and objectives. Most importantly, the reflective teaching approach encourages teachers to develop constant and active reflections on their own teaching for continuous improvements in teaching and professional development. Hence, more research or teacher training programs should be encouraged in the relevant fields.

Table 3 and Table 4 show the participants' feedback to guest speeches of experienced English teachers on creative teaching ideas for teaching English to elementary students. Positive results have been drawn on the subjects' feedback to both guest speeches. According to Table 3 and Table 4, most subjects (more than 60\% ) thought that the speech contents of the 2 guest speeches were appropriate (item $1)$, and the new concepts and information provided by both speeches were very helpful for their teaching (item 2). Also, more than $60 \%$ of the subjects thought that the experience sharing by both speeches assisted them to improve their teaching techniques and effectiveness (item 7), and equipped them with more teaching strategies and made them more confident in teaching. Furthermore, more than $90 \%$ of the teachers in the training program indicated that guest speeches were well-prepared (item 3) because the speaker brought a lot of supplementary teaching materials, teaching aids, game sets and students' assignments; the teaching experiences shared by both speakers were applicable to and helpful for their own teaching (item 4), and the experience sharing by both speakers inspired their creativity (item 6). In addition, more than half of the teachers agreed that the teaching experiences shared by both speakers enhanced their professional knowledge and 
development (item 5) and assisted them to incorporate professional knowledge, theoretical background and teaching practices (item 9). The rich resources could inspire the teachers in this study in several ways and evoke their creativities to adapt some of the materials or activities to their own classroom.

However, only about $40 \%$ of the subjects in the study indicated that he teaching tips and strategies shared by Speaker 1 were practical and applicable to their teaching, and more than $60 \%$ of them held neutral opinions. Those teachers' concerns of the practicality of the shared ideas by Speaker 1 might be due to time concerns (about 2 hours weekly) for the language teaching in the contexts of public schools, and some of the reading instruction tips or extensive reading activities might need more time to have positive effects on pupils' development of reading proficiency. Nevertheless, most teachers held positive attitudes and opinions about the ideas and creative activities shared by the first speaker.

Table 3: Feedback to guest speech 1

\begin{tabular}{|c|c|c|c|c|c|c|c|}
\hline & Items & Mean & 5 & 4 & 3 & 2 & 1 \\
\hline 10 & The speech contents of Speaker 1 are appropriate. & 3.69 & 8 & 54 & 39 & 0 & 0 \\
\hline 2. & $\begin{array}{l}\text { The new concepts and information provided by } \\
\text { Speaker } 1 \text { are very helpful for my teaching. }\end{array}$ & 3.69 & 8 & 54 & 39 & 0 & 0 \\
\hline 3. & Guest Speaker 1 was well-prepared. & 3.92 & 15 & 62 & 23 & 0 & 0 \\
\hline 4. & $\begin{array}{l}\text { The teaching experiences shared by Speaker } 1 \text { are } \\
\text { applicable to and helpful for my own teaching. }\end{array}$ & 3.77 & 8 & 62 & 31 & 0 & 0 \\
\hline 5 . & $\begin{array}{l}\text { The teaching experiences shared by Speaker } 1 \text { enhance } \\
\text { my professional knowledge and development. }\end{array}$ & 3.62 & 8 & 46 & 46 & 0 & 0 \\
\hline 6. & $\begin{array}{l}\text { The experience sharing by Speaker } 1 \text { inspires my } \\
\text { creativity. }\end{array}$ & 3.92 & 15 & 62 & 23 & 0 & 0 \\
\hline 7. & $\begin{array}{l}\text { The teaching experiences shared by Speaker } 1 \text { assist } \\
\text { me to improve my teaching techniques and } \\
\text { effectiveness. }\end{array}$ & 3.77 & 15 & 46 & 39 & 0 & 0 \\
\hline
\end{tabular}

8. The teaching experiences shared by Speaker 1 equip me with more teaching strategies and make me more confident in teaching.

9. The guest speech 1 assisted me to incorporate professional knowledge, theoretical background and $\begin{array}{llllll}3.77 & 15 & 46 & 39 & 0 & 0\end{array}$ teaching practices.

10. The teaching tips and strategies shared by Speaker $1 \quad \begin{array}{lllllll}3.46 & 7 & 31 & 62 & 0 & 0\end{array}$ are practical and applicable to my teaching. 
In sum, positive feedback has been drawn from the subjects (English teachers) in this study. Most feedback indicated the applicability and practicality of the shared ideas, activities and task designs to the English teaching in the elementary schools. The most importantly, those ideas shared by the experienced teachers inspired the teachers in the training program described in this study, and enhanced their professional development in teaching knowledge, skills and strategies.
Likewise, the qualitative analyses of the subjects' responses to guest speeches provide supportive descriptions and explanations. Most subjects indicate that some of the adapted games, such as SET and UNO, and grammatical teaching tips shared by the Speaker 1 are practical, applicable and inspiring. Some subjects stated that they could adapt the ideas or options shared by Speaker 1 and develop their own teaching aids, and applied the teaching aids for teaching of letter, vocabulary and grammar.

Table 4: Feedback to guest speech 2

\begin{tabular}{|c|c|c|c|c|c|c|c|}
\hline & Items & Mean & 5 & 4 & 3 & 2 & 1 \\
\hline 1. & The speech contents of Speaker 2 are appropriate. & 4.23 & 39 & 46 & 15 & 0 & 0 \\
\hline 2. & $\begin{array}{l}\text { The new concepts and information provided by Speaker } 2 \\
\text { are very helpful for my teaching. }\end{array}$ & 4.15 & 31 & 54 & 15 & 0 & 0 \\
\hline 3. & Guest Speaker 2 was well-prepared. & 4.38 & 46 & 46 & 8 & 0 & 0 \\
\hline 4. & $\begin{array}{l}\text { The teaching experiences shared by Speaker } 2 \text { are } \\
\text { applicable to and helpful for my own teaching. }\end{array}$ & 4.00 & 31 & 39 & 31 & 0 & 0 \\
\hline 5. & $\begin{array}{l}\text { The teaching experiences shared by Speaker } 2 \text { enhance my } \\
\text { professional knowledge and development. }\end{array}$ & 4.00 & 31 & 39 & 31 & 0 & 0 \\
\hline 6. & The experience sharing by Speaker 2 inspires my creativity. & 4.08 & 23 & 62 & 15 & 0 & 0 \\
\hline 7. & $\begin{array}{l}\text { The teaching experiences shared by Speaker } 2 \text { assist me to } \\
\text { improve my teaching techniques and effectiveness. }\end{array}$ & 3.92 & 23 & 46 & 31 & 0 & 0 \\
\hline 8. & $\begin{array}{l}\text { The teaching experiences shared by Speaker } 2 \text { equip me } \\
\text { with more teaching strategies and make me more confident } \\
\text { in teaching. }\end{array}$ & 3.92 & 23 & 46 & 31 & 0 & 0 \\
\hline 9. & $\begin{array}{l}\text { The guest speech } 2 \text { assisted me to incorporate professional } \\
\text { knowledge, theoretical background and teaching practices. }\end{array}$ & 4.00 & 23 & 54 & 23 & 0 & 0 \\
\hline & $\begin{array}{l}\text { The teaching tips and strategies shared by Speaker } 2 \text { are } \\
\text { practical and applicable to my teaching. }\end{array}$ & 4.00 & 31 & 39 & 31 & 0 & 0 \\
\hline
\end{tabular}

*N =13; 5=Strongly Agree; 4 =Agree; 3 =Partly Agree; $2=$ Disagree; $1=$ Strongly Disagree

Besides, most subjects indicate that some of the adapted games, such as 
Gobang and 5-sense teaching, and grammatical teaching aids and some creative teaching ideas shared by the Speaker 2 are practical, applicable and inspiring. Some subjects thought Speaker 2 was very passionate and the creative ideas and teaching resources or aids were very inspiring and helpful. Also, some of them acknowledged the teaching passions shown by the second speaker. Finally, the second speaker inspired most of the subjects in this study for more options to integrate reading and writing to language class.

Some excerpts of students' feedback to the guest speeches are described as follows:

Guest Speaker 1 provided a variety of options for class activities, and I can apply them to my class with slight adjustments or modifications. (T002)

A variety of teaching activities, such as SET and UNO, and other grammar analyses and instruction tips. (T005)

The Uno game and activities can be incorporated to the theme-based vocabulary learning. (T001)

Guest Speaker 2 adopted and modified a lot of teaching activities, and this inspired me that I could change or modify mine as well. (T013)

In sum, the qualitative findings of subjects' feedback to the course, reflective teaching and guest speeches were consistent with the quantitative results discussed in the earlier sections, and indicate the positive effects of the course design, the positive influences of reflective teaching and guest speeches in this study.

\section{Learning Tasks That Were Considered Beneficial}

Table 5 illustrates the subjects' feedback to the beneficial $\operatorname{task}(\mathrm{s})$ in the reflective-teaching based program. Accordingly, the teaching ideas shared by the guest speakers, who are experienced teachers, are considered the most helpful. The result is consistent with the discussions in the previous section about participating English teachers' feedback to the class for the open-ended question regarding the most inspiring task in the program. The following are some excerpts from the teachers' feedback to one of the open-ended questions in the course feedback questionnaire.

From the sharing of the experienced teachers, I've learned some new different ways of teaching and a lot of practical teaching strategies that I can adapt and use in my own class. (T004)

$T$ invited some $T s$ to share their practical experiences. They really gave me some good ideas, and I couldn't wait to try them in my class. (T013)

The feedback provided by the English teachers who participated in this short-term program indicates that the sharing of ideas and experiences by the experienced teachers, the guest speakers, inspire them with new ideas that can be employed in their classes, and they are willing to try them out and improve their teaching. It seems that the sharing by 
the experienced teachers evoke the participants of the course to reflect on the possibilities to incorporate the new ideas to their classes, and try to make a difference.

The second most beneficial tasks are teaching diagnosis / problem discussions and on-line resources. Teaching demonstrations and The comments and suggestions provided by peers and the class teacher after teaching demonstrations were very practical. (T002)

The class discussions with peers and teaching demonstration inspired me to try different teaching methods and teaching ideas...With the rich resources and contents provided by the class teacher, I learnt a lot and made a progress in a short period of time. (T004)

The resources provided by the class teacher, real practice (demonstration), class discussions were all very helpful for my teaching. (T011)

The results above in Table 5 and feedback by the participating teachers supplementary teaching activities / skills were also considered helpful. The following excerpts from the teachers' feedback to one of the open-ended questions in the course feedback questionnaire can lend some supports for the results in Table 5.

indicate that the demonstrating teachers appreciate others' comments and suggestions, and they are willing to accept the advice and improve their own teaching. Besides, those teachers think class discussions with peers and the lecturers could give them more inspirations than the paper-based self-assessment or peer-assessment. Due to the time limit of the intensive program, the researcher was not able to conduct follow-up interviews addressing on this issue. Future research could take this factor into account when tasks are designed for reflective teaching.

Table 5: The most beneficial learning tasks

\section{Task}

1. Teaching demonstrations

2. Lesson plan composition

3. Supplementary teaching activities

4. Lectures on textbook contents

5. Self-assessment after teaching demonstrations

6. Peer-assessment after teaching demonstrations

7. Supplementary teaching skills

8. Ideas shared by guest speakers

9. Lectures on teaching methodologies and approaches

10. Teaching diagnosis and problem discussions

11. Sharing of additional on-line resources

\begin{tabular}{cc} 
No. of subjects & Ranking \\
/ Percentage & \\
$8(61.54 \%)$ & 3 \\
$4(30.77 \%)$ & \\
$7(53.85 \%)$ & 4 \\
$4(30.77 \%)$ & \\
$4(30.77 \%)$ & \\
$4(30.77 \%)$ & \\
$7(53.85 \%)$ & 4 \\
$10(76.92 \%)$ & 1 \\
$3(23.08 \%)$ & \\
$9(69.23 \%)$ & 2 \\
$9(69.23 \%)$ & 2 \\
\hline
\end{tabular}

Note. Total No. of subjects $=13$ 


\section{CONCLUSION}

The present study was designed to guide English teachers of elementary schools in southern Taiwan to practice reflective teaching and to understand the medium of instructions. Through reflections on teaching demonstration, the lecturer's and peers' comments and suggestions, the subjects (teachers) were guided to self-assess strengths and weaknesses of their own instructions, and were equipped with strategies to cope with problems in their classes. The quantitative and qualitative analyses all indicate positive feedback of the reflective teaching on teaching improvements, diagnosis of teaching strengths and weaknesses as well as awareness-raising for teachers' reflections in their future teaching. Specifically, reflective teaching assisted teachers to be more aware of the importance of understanding students' needs, and helped them improve their class management skills, instructions and class interactions. It also influenced teachers to remind themselves of the importance to constantly reflect on their own teaching and ways to improve their instructions. However, the length of the present study (3 weeks) was comparatively short, so the interpretations and generalizations of the study findings should be careful. More relevant studies on effects of reflective teaching for a longer period of time, and involvements of more subjects should be encouraged in the future. For further verifications of teachers' applications of the reflective teaching and learnt techniques from this program, follow-up studies with class visits, videotaped teaching and semi-structured interviews are suggested. Also, further research can be conducted to compare the long-turn teaching performances between reflective teachers and non-reflective teachers and students' performances in reflective teaching and non-reflective teaching classes to have more holistic understanding of the effects of reflective teaching.

\section{REFERENCE}

Bailey, K, Curtis, A. \& Nunan, D. (2001). Pursuing professional development: The self as source. Boston, MA: Heinle \& Heinle.

Chio, C. P. (2004). A teacher's reflections on teaching processes. Unpublished master's thesis, National Taipei University of Education, Taipei, Taiwan.

Clarke, R., \& Croft, P. (1998). Critical reading for the reflective practitioner. Oxford, UK: Elsevier ButterworthHeinemann.

Costa, A. L. \& Kallick, B. (2000). Getting into the habit of reflection. Educational leadership, April, pp. 60-66.

Danielowich, R. (2007). Negotiating the conflicts: Reexamining the structure and function of reflection in science teacher learning. Science Education, 91(4), pp. 629-663. 
Dewey, J. (1933). How we think: A restatement of the relation of reflective thinking to the education process. Chicago, IL.: D. C. Heath.

Downey. J. (2008). 'It's not as easy as it looks': Pre-service teachers' insights about teaching emerging from an innovative assignment in educational psychology. Teaching Educational Psychology, 3(1), pp. 1-11.

Hsu, C. S. (2009). The analysis of the reflection of students and its implication on teaching of teaching practicum course. Journal of Educational Research and Development, 5(1), pp. 35-58.

Kemmis, S. (1985). Action research and the politics of reflection. In Boud, D., Keogh., \& Walker, D. (Eds.) Reflection: Turning experience into learning. London: Kogan Page.

Moon, J. A. (2006). Learning journals: A handbook for reflective practice and professional development (6th ed.). New York: Routledge.

Moran, M. J. (2007). Collaborative action research and project work: Promising practices for developing collaborative inquiry among early childhood pre-service teachers. Teaching and Teacher Education: An International Journal of Research and Studies, 23(4), pp. 418-431.

Narvaéz, C. Q. (2010). How can the practice of reflective teaching promote professional develop- ment in each of the constituents of teacher educationknowledge, skills, attitudes and awareness? Retrieved from http://www.eumed.net/rev/tlatemoani/ 02/cqn.pd.

Orland-Barak, L. \& Yinon, H. (2007). When theory meets practice: What student teachers learn from guided reflection on their own classroom discourse. Teaching and Teacher Education, 23(6), pp. 957-969.

Pedro, J. Y. (2005). Reflecting in teacher education: Exploring pre-service teachers' meaning of reflective practice. Reflective Practice, 6(10), pp. 49-66.

Posner, G. J. (2005). Field experience: A guide to reflective teaching ( $6^{\text {th }} \mathrm{ed}$.). Boston, MA: Pearson-Allyn \& Bacon.

Rodman, G. J. (2010). Facilitating the teaching-learning process through the reflective engagement of pre-service teachers. Australian Journal of Teacher Education, 35(2), pp. 20-35.

Schön, D.A. (1983). The reflective practitioner: How professionals think in action. New York: Basic Books.

Schön, D.A. (1987). Educating the reflective practitioner: toward a new design for teaching and learning in the professions. San Francisco, CA: Jossey Bass, Inc.

Rodman, G. J. (2010). Facilitating the teaching-learning process through 
Indonesian Journal of Applied Linguistics, Vol. 3 No. I, July 20I3, pp. 8I-I02

the reflective engagement of

pre-service teachers. Australian

Journal of Teacher Education, 35(2), pp. 20-35.

Tsai, F. C. (2004). A study on reflective behaviors and teaching beliefs of pre-service teachers in teaching practicum course. Unpublished master's thesis, National Sun Yat-sen University, Kaohsiung, Taiwan.

Tseng, W. C. (2002). A study on reflections of pre-service teachers: A case study of class management course. Unpublished master's thesis,
National Sun Yat-sen University, Kaohsiung, Taiwan.

Yang, M. L. (2004). Research on teaching reflections of math teachers in elementary schools. Unpublished master's thesis, National Taipei University of Education, Taipei, Taiwan.

Yuen, H.Y.(2005). Effects of mobile learning on students' learning. Unpublished master's thesis, Chung Yuan Christian University, Taoyuan, Taiwan. 


\section{Appendix I}

Transcripts of Open-ended Question Feedback to the Course and

Reflective-Teaching

\section{Feedback to the Course}

16. What is the most inspiring or the inspiration you've got from the course?

17. Other feedback or reflections to the course?

\begin{tabular}{|c|c|}
\hline Id & Feedback \\
\hline T001 & $\begin{array}{l}\text { The course helped me re-examine teaching of English reading, and the relationship between } \\
\text { English reading and writing. }\end{array}$ \\
\hline T002 & $\begin{array}{l}\text { The comments and suggestions provided by peers and the class teacher after teaching } \\
\text { demonstrations were very practical. In the course, teacher reviewed some language teaching } \\
\text { approaches and recalled my memories. }\end{array}$ \\
\hline T003 & $\begin{array}{l}\text { The course inspired me to integrate knowledge, theory and practice. } \\
\text { I learnt a lot. Thank you. }\end{array}$ \\
\hline T004 & $\begin{array}{l}\text { The class discussions with peers and teaching demonstration inspired me to } \\
\text { Try different teaching methods and teaching ideas. From the sharing of } \\
\text { the experienced teachers, I've learned some new different ways of teaching } \\
\text { and a lot of practical teaching strategies that I can adapt and use in my own class. } \\
\text { With the rich resources and contents provided by the class teacher, I learnt } \\
\text { a lot and made a progress in a short period of time. }\end{array}$ \\
\hline T005 & $\begin{array}{l}\text { 1. Review a lot of teaching methods and approaches. } \\
\text { 2. Know several English teachers and can discuss together for more teaching strategies. } \\
\text { 3. The course instructor prepared rich resources and contents that were very helpful for us. } \\
\text { Although the class is demanding and tiring, I learnt a lot. }\end{array}$ \\
\hline T007 & $\begin{array}{l}\text { Teaching is an art, and takes time. Through observations, feedback or comments as well as } \\
\text { theoretical backgrounds, we are provided with good ideas and chances for constant } \\
\text { improvements in teaching. } \\
\text { Thanks for teacher's rich resources. }\end{array}$ \\
\hline T008 & $\begin{array}{l}\text { 1. Share practical teaching experiences with other English teachers. } \\
\text { 2. The lectures refreshed my concepts and inspired me new ideas that were very helpful for } \\
\text { my teaching. } \\
\text { Thanks for teacher's efforts and classmates' help and sharing. }\end{array}$ \\
\hline T009 & $\begin{array}{l}\text { The course helped me rethink my previous course and activity designs, and } \\
\text { re-evaluate if they are consistent with my teaching objectives. }\end{array}$ \\
\hline T010 & Rethinking my teaching style. \\
\hline T011 & $\begin{array}{l}\text { 1. The resources provided by the class teacher, real practice (demonstration), class } \\
\text { discussions were all very helpful for my teaching. } \\
\text { 2. The course helped me understand how to incorporate on-line resources to enhance my } \\
\text { students' learning, but I need to pay attention to if the applications of on-line resources } \\
\text { would be consistent with my teaching needs and objectives. Also, the learners play a } \\
\text { very critical role in my course design. } \\
\text { Thanks for teacher's sharing of rich and valuable resources. }\end{array}$ \\
\hline T012 & $\begin{array}{l}\text { To rethink my teaching all the time and to try story reading in the limited time and I think that } \\
\text { will make differences. }\end{array}$ \\
\hline
\end{tabular}

\section{Feedback to Reflective Teaching}

16. What is the most inspiring or something you would like to share?

\begin{tabular}{cl}
\hline Id & \multicolumn{1}{c}{ Feedback } \\
\hline T001 & $\begin{array}{l}\text { I have new understanding of the roles and importance of warm-up in each lesson. The } \\
\text { warm-up section is not only for review, it is important and helpful for } \\
\text { students' integrations of the old knowledge with the new content. }\end{array}$ \\
\hline T002 & $\begin{array}{l}\text { Reflective teaching reminds me to constantly reflect on my lessons and examine if they } \\
\text { meet my students' needs. }\end{array}$ \\
\hline T003 & I start to reflect on my own teaching actively. \\
\hline
\end{tabular}




\begin{tabular}{ll}
\hline T004 & From other teachers' experiences, I reflect on my teaching, especially my weakness. \\
\hline T005 & $\begin{array}{l}\text { Through reflections, I can understand the strengths and weakness of my teaching } \\
\text { better. }\end{array}$ \\
\hline T006 & $\begin{array}{l}\text { The classmates' and teacher's suggestions after the teaching demonstrations helped } \\
\text { me find my strengths and the parts that need to be improved. }\end{array}$ \\
\hline T007 & $\begin{array}{l}\text { Through teaching demonstrations, I could observe different teaching procedures and } \\
\text { processes, and justify which is better and the key to be a successful teaching so } \\
\text { that I can modify and adjust my teaching style. }\end{array}$ \\
\hline T008 & $\begin{array}{l}\text { Reflective teaching helps me reexamine my teaching procedures and my } \\
\text { weaknesses. }\end{array}$ \\
\hline T009 & $\begin{array}{l}\text { Reflective teaching helps me be aware of my own shortcoming and learn from } \\
\text { others' advantages or good activity designs. }\end{array}$ \\
\hline T010 & By watching other teachers'demonstrations, I can reflect on my own teaching. \\
\hline T011 & $\begin{array}{l}\text { 1. Although I don't really like teaching demonstrations, I can examine my own teaching } \\
\text { carefully to be aware of my weaknesses and learn from others' strengths. } \\
\text { Two teaching demonstrations in a short-term program (2.5 weeks) are a little bit } \\
\text { demanding. }\end{array}$ \\
\hline T012 & \begin{tabular}{l} 
Reflections help me to improve my teaching a lot. \\
\hline T013
\end{tabular} I can constantly improve my teaching during the teaching demonstrations. \\
\hline
\end{tabular}

\section{Feedback to the Guest Speech 1}

11. What do you think is the most practical thing shared by the Guest Speaker 1?

\begin{tabular}{ll}
\hline Id & \multicolumn{1}{c}{ Feedback } \\
\hline T001 & The game of Uno is more applicable. \\
\hline T002 & $\begin{array}{l}\text { I need to understand parents' expectations to the school education. In addition, Guest } \\
\text { Speaker 1 provided a variety of options for class activities, and I can apply them to } \\
\text { my class with slight adjustments or modifications. }\end{array}$ \\
\hline T003 & TPR activity \\
\hline T004 & Teaching activities \\
\hline T005 & $\begin{array}{l}\text { A variety of teaching activities, such as SET and UNO, and other grammar analyses } \\
\text { and instruction tips. }\end{array}$ \\
\hline T007 & Matching games are quite practical and applicable. \\
\hline T008 & Learning phonics by singing is helpful for students' memorization. \\
\hline T011 & $\begin{array}{l}\text { Teach some concepts of teaching of grammar and writing, and provide some } \\
\text { information about applications of games for learning. }\end{array}$ \\
\hline T012 & The "Uno" game. \\
\hline T013 & She invented several practical and creative activities that inspire us to brainstorm more. \\
\hline
\end{tabular}

Feedback to the Guest Speech 1

12. After the sharing of the Guest Speaker 1, what new ideas were inspired? How can I incorporate the new ideas into my teaching?

\begin{tabular}{ll}
\hline Id & \multicolumn{1}{c}{ Feedback } \\
\hline T001 & The Uno game and activities can be incorporated to the theme-based vocabulary learning. \\
\hline T003 & Cooperative learning; contests \\
\hline T004 & The applicability of grammatical concepts to my present teaching. \\
\hline T005 & The SET game can be employed in my teaching. \\
\hline T007 & $\begin{array}{l}\text { The teaching of Guest Speaker 1 is more suitable for autonomous learning, and it's } \\
\text { comparatively more difficult to be applied for teaching. }\end{array}$ \\
\hline T008 & The matching game and activities can be useful for both letter and vocabulary learning. \\
\hline T011 & $\begin{array}{l}\text { With simple tables and some mnemonic rhymes, it's easier to teach kids about } \\
\text { complicated grammatical concepts. The speaker's sharing inspired me to think how to } \\
\text { simplify instructions of complicated grammatical rules. }\end{array}$ \\
\hline T012 & Kids can learn the forms of verb with funny way. \\
\hline T013 & $\begin{array}{l}\text { She adopted and modified a lot of teaching activities, and this inspired me that I } \\
\text { could change or modify mine as well. }\end{array}$ \\
\hline
\end{tabular}

Feedback to the Guest Speech 2 
11. What do you think is the most practical thing shared by the Guest Speaker 2?

\begin{tabular}{|c|c|}
\hline Id & Feedback \\
\hline T001 & Cook Book and reading reflection logs are practical. \\
\hline T002 & $\begin{array}{l}\text { 5-sense teaching and other creative teaching ideas. The speaker provided a useful } \\
\text { booklist that is a useful resource for creative language teaching. }\end{array}$ \\
\hline T003 & theme-based teaching \\
\hline T004 & Students' worksheets and teachers' resources or reference books \\
\hline T005 & $\begin{array}{l}\text { 1. Use a variety of small teaching aids, e.g. a slot machine } \\
\text { 2. The board of Gobang game is useful for teaching, especially grammatical structures. }\end{array}$ \\
\hline T007 & Teaching requires a lot of passions and surprises. \\
\hline T008 & We need to give students surprises often to inspire their interests. \\
\hline T009 & Integrations of writing instructions; shared a lot of useful resources. \\
\hline T011 & $\begin{array}{l}\text { 1. Share a lot of good websites and reference books or other resources. } \\
\text { 2. A variety of teaching aids; collecting games and enhance students' multiple-senses } \\
\text { learning. }\end{array}$ \\
\hline T012 & The teaching for writing. \\
\hline T013 & ing tips in reading and writing practice for our referenc \\
\hline
\end{tabular}

\section{Feedback to the Guest Speech 2}

12. After the sharing of the Guest Speaker 2, what new ideas were inspired? How can I incorporate the new ideas into my teaching?

\begin{tabular}{|c|c|}
\hline Id & Feedback \\
\hline T001 & $\begin{array}{l}\text { Cook Book is more useful; Speaker } 2 \text { shared a lot of options for teaching food, } \\
\text { and they are quite applicable. }\end{array}$ \\
\hline T002 & $\begin{array}{l}\text { A lot of ideas can be used in teaching. I'll think about more teaching varieties to make my } \\
\text { teaching more interesting and will be more interested in practicing the } \\
\text { language. }\end{array}$ \\
\hline T003 & Creative activities applicable for daily activities \\
\hline T004 & Extracurricular reading materials (e.g. books; magazines) \\
\hline T005 & Situational decorations (e.g. Halloween activities and decorations.) \\
\hline T007 & $\begin{array}{l}\text { Some toys from the toy shop can be used in teaching; asking students to read at } \\
\text { the class beginning can be helpful for training of language awareness. }\end{array}$ \\
\hline T008 & $\begin{array}{l}\text { Some creative teaching aids (e.g. paper plates to make snowmen; applicable on } \\
\text { Christmas) }\end{array}$ \\
\hline T009 & Try to incorporate more writing activities \\
\hline T011 & $\begin{array}{l}\text { Guest Speaker } 2 \text { is very passionate, and can clearly guide us to understand how to design } \\
\text { courses from different aspects and design a various and attractive course. }\end{array}$ \\
\hline T012 & $\begin{array}{l}\text { To teach kids to writing in simple context and then increasing the difficulty of } \\
\text { contents. }\end{array}$ \\
\hline T013 & I can incorporate appropriate reading and writing activities to my English class. \\
\hline
\end{tabular}

